\title{
Insight into cis-to-trans Olefin Isomerisation Catalysed by Group 4 and 6 Cyclopentadienyl Compounds
}

\author{
Ghaita Chahboun, ${ }^{[a]}$ Cristina E. Petrisor, ${ }^{[b]}$ Enrique Gómez-Bengoa, ${ }^{[c]}$ Eva Royo, ${ }^{*[b]}$ and \\ Tomás Cuenca*[b]
}

Keywords: Hydrides / Isomerization / Molybdenum / Tungsten / Zirconium

Intramolecular isomerisation of the pendant allyl unit present in the model compound $\left[\mathrm{MoH}\left(\eta^{5}-\mathrm{C}_{5} \mathrm{H}_{4} \mathrm{SiMe}_{2} \mathrm{CH}_{2} \mathrm{CH}=\mathrm{CH}_{2}\right)\right.$ $(\mathrm{CO})_{3}$ ] reported before was investigated by DFT calculations. The coordination of $\mathrm{CO}$ and the splitting of the agostic Mo$\mathrm{H}$ interactions found in metallacyclic transition states stabilise the cis and trans hydride compounds $\left[\mathrm{MoH}\left(\eta^{5}-\mathrm{C}_{5} \mathrm{H}_{4} \mathrm{Si}-\right.\right.$ $\left.\mathrm{Me}_{2} \mathrm{CH}=\mathrm{CHCH}_{3}\right)(\mathrm{CO})_{3}$ ] relative to the corresponding tricarbonyl molybdenum alkyl metallacycles. A comparison with an analogous zirconium system is included. To contrast these results with the behaviour of metal hydride cyclopentadienyl compounds, which have no intramolecular alkene functionality, group 4 and 6 derivatives such as $\left[\mathrm{Zr}\left(\eta^{5}\right.\right.$ $\left.\left.\mathrm{C}_{5} \mathrm{H}_{4} \mathrm{SiMe}_{2}-\eta^{1}-\mathrm{N} t \mathrm{Bu}\right)\left(\eta^{5}-\mathrm{C}_{5} \mathrm{H}_{4} \mathrm{SiMe}_{2} \mathrm{CH}_{2} \mathrm{CH}_{2}-\eta^{1}-\mathrm{CH}_{2}\right)\right]$ $\left[\mathrm{MH}\left(\eta^{5}-\mathrm{C}_{5} \mathrm{HMe}_{4}\right)(\mathrm{CO})_{3}\right][\mathrm{M}=\mathrm{Mo}(\mathbf{3}), \mathrm{W}(\mathbf{4})]$, and $\left[\mathrm{ZrH}\left(\eta^{5}-\right.\right.$
$\left.\left.\mathrm{C}_{5} \mathrm{H}_{4} \mathrm{SiMe}_{2}-\eta^{1}-\mathrm{N} t \mathrm{Bu}\right)\left(\eta^{5}-\mathrm{C}_{5} \mathrm{H}_{4} \mathrm{R}\right)\right]\left[\mathrm{R}=\mathrm{H}(\mathbf{5}), \mathrm{SiMe}_{3}(\mathbf{6})\right]$ were examined as selective catalysts for the intermolecular isomerisation of the terminal olefins allyltrimethylsilane (A) and 4-methyl-1-pentene (B). Zirconium hydride compounds were the most efficient catalysts. Compound $\mathbf{4}$ catalysed the same reaction but required heating at $140{ }^{\circ} \mathrm{C}$, whereas compound 3 was inactive due to a dehydrogenation process, which produced the dinuclear compound $\left[\mathrm{Mo}\left(\eta^{5}-\mathrm{C}_{5} \mathrm{HMe}_{4}\right)(\mathrm{CO})_{3}\right]_{2}(\mathbf{7})$. Reaction of $\mathbf{4}$ and 5 with the internal alkenes trimethyl(1propenyl)silane (C) and 4,4-dimethyl-2-pentene (D) favoured cis-to-trans isomer conversion with poor production of the corresponding terminal olefins.

() Wiley-VCH Verlag GmbH \& Co. KGaA, 69451 Weinheim, Germany, 2009)

\section{Introduction}

Metal-catalysed isomerisation of olefinic double bonds has been extensively studied and exploited as a desired reaction in many industrial processes. ${ }^{[1,2]}$ However, some key issues with practical implications remain unresolved. In particular, it is not clear what controls, with certain catalysts, selectivity towards the formation of cis olefins versus the generally more thermodynamically stable trans isomers. ${ }^{[3]}$ Within this context, transition-metal hydrides are of fundamental importance, as they are involved as catalysts or proposed intermediates in alkene isomerisation reactions. ${ }^{[4-8]}$ In particular, when a $\mathrm{M}-\mathrm{H}$ bond is present in the catalyst, the generally accepted mechanism involves olefin coordination to give a $\pi$-olefin metal complex, which by

[a] Université Abdelmalek Essaâdi, Faculté des Sciences, Departement de Chimie - Laboratoire de Chimie Organique,

Mhannech II, B.P: 2121 Tétouan, Marocco

[b] Departamento de Química Inorgánica, Facultad de Ciencias, Universidad de Alcalá,

28871 Alcalá de Henares, Madrid, Spain

Fax: +34918854683

E-mail: tomas.cuenca@uah.es eva.royo@uah.es

[c] Facultad de Ciencias Químicas, Universidad del País Vasco, 20018, San Sebastian, Spain

E-mail: enrique.gomez@ehu.es

Supporting information for this article is available on the WWW under http://www.eurjic.org or from the author. subsequent addition-elimination reactions makes isomerisation possible. ${ }^{[4]}$

The design of model compounds that contain cyclopentadienyl ligands with a hemilabile binding profile has proved to be a useful strategy to stabilise intermediates that are transient under typical catalytic conditions. ${ }^{[7-9]}$ We began our investigations of early transition metal olefin isomerisation reactions with a family of allyldimethylsilyl- $\eta^{5}$ cyclopentadienyl hydride group 4 and 6 metal model systems. ${ }^{[7,8]}$ Whereas group 6 metal compounds of formula $\left[\mathrm{MH}\left(\eta^{5}-\mathrm{C}_{5} \mathrm{R}_{4} \mathrm{SiMe}_{2} \mathrm{CH}_{2} \mathrm{CH}=\mathrm{CH}_{2}\right)(\mathrm{CO})_{3}\right]$ can isomerise the intramolecular pendant allyl unit selectively to the transprop-1-en-yl-dimethylsilyl group, ${ }^{[7]}$ the allyldimethylsilyl cyclopentadienyl $\mathrm{Zr}$ hydride compound $\left[\mathrm{ZrH}\left(\eta^{5}-\mathrm{C}_{5} \mathrm{H}_{4} \mathrm{SiMe}_{2}-\right.\right.$ $\left.\left.\eta^{1}-\mathrm{N} t \mathrm{Bu}\right)\left(\eta^{5}-\mathrm{C}_{5} \mathrm{H}_{4} \mathrm{SiMe}_{2} \mathrm{CH}_{2} \mathrm{CH}=\mathrm{CH}_{2}\right)\right]$ (1) evolves into the six-membered zirconacycle derivative $\left[\mathrm{Zr}\left(\eta^{5}-\mathrm{C}_{5} \mathrm{H}_{4^{-}}\right.\right.$ $\left.\left.\mathrm{SiMe}_{2}-\eta^{1}-\mathrm{N} t \mathrm{Bu}\right)\left(\eta^{5}-\mathrm{C}_{5} \mathrm{H}_{4} \mathrm{SiMe}_{2} \mathrm{CH}_{2} \mathrm{CH}_{2}-\eta^{1}-\mathrm{CH}_{2}\right)\right]$ DFT calculations on these model zirconium systems confirmed ${ }^{[8]}$ that formation of derivative $\mathbf{2}$ is a consequence of the higher thermodynamic stability of the six-membered zirconacycle compound relative to that of $\mathrm{Zr}$ hydride derivative 1 and the analogous trans-prop-1-en-yl-dimethylsilylcyclopentadienyl complex $\left[\mathrm{ZrH}\left(\eta^{5}-\mathrm{C}_{5} \mathrm{H}_{4} \mathrm{SiMe}_{2}-\eta^{1}-\right.\right.$ $\left.\mathrm{N} t \mathrm{Bu})\left(\eta^{5}-\mathrm{C}_{5} \mathrm{H}_{4} \mathrm{SiMe}_{2} \mathrm{CH}=\mathrm{CHCH}_{3}\right)\right]$.

This result moved us to perform analogous theoretical calculations on the allyldimethylsilylcyclopentadienyl Mo hydride compound described before ${ }^{[7,8]}$ to compare the be- 
haviour of both group 4 and 6 compounds and to provide a detailed picture of the favoured pathways followed for these metal hydride species in their isomerisation processes. In addition, the ability of these hydride organometallic derivatives to participate in intramolecular allyl isomerisation ${ }^{[7,8]}$ prompted us to test similar $\mathrm{Mo}, \mathrm{W}$ and $\mathrm{Zr}$ cyclopentadienyl compounds lacking an alkene functionality in the cyclopentadienyl ring as selective olefin isomerisation catalysts.

\section{Results and Discussion}

\section{Computational Study}

The widely accepted isomerisation mechanism for 18electron carbonyl species requires previous displacement of one carbonyl ligand by the olefinic moiety to afford allyl cyclopentadienyl dicarbonyl hydride molybdenum species with the required cis geometry between the hydride and the olefin ligands. Accordingly, we could not locate any transition state involving isomerisation of the double bond in a monocyclopentadienyl hydride molybdenum complex bearing three carbonyl ligands, whereas Mo complexes of 16 (loss of one neutral ligand) or 20 electrons (concomitant coordination of the olefin and three carbonyl groups to this type of metal centre) were computationally unstable. Thus, the transition states (TS) for dissociation of one carbonyl group by the double bond were located and the intrinsic reaction coordinates (IRC) undoubtedly showed that they connect the Mo complexes allyl-1 and allyl-2 (TS1), cis-1 and cis-2 (TS8) and trans-1 and trans-2 (TS9) (Figures 1 and 2). The activation energies of the three processes are rather large. For example, an activation enthalpy of
$40.3 \mathrm{kcal} / \mathrm{mol}$, with a free energy value of $40.6 \mathrm{kcal} / \mathrm{mol}$ was calculated for conversion of allyl-1 into allyl-2. The loss of one carbonyl ligand is a highly endothermic process, $\left(H_{\text {allyl-2 }}-H_{\text {allyl-1 }}=21.2 \mathrm{kcal} / \mathrm{mol}\right)$, although the entropic benefit of splitting allyl-1 into two molecules (namely, carbonyl and allyl-2) reduced the value of $\Delta G$ to $14.5 \mathrm{kcal} / \mathrm{mol}$. Similar activation parameters were obtained for TS8 and TS9. Allyl-2 can suffer migratory insertion of the hydride ligand into the double bond in either of two ways, TS2 or TS3, to afford complex A or $\mathbf{B}$, respectively, as shown in Figure 1. Both transition states have similar activation energies, but metallacycle $\mathbf{B}$ is the thermodynamically preferred species by ca. $5 \mathrm{kcal} / \mathrm{mol}$ and the only one that opens access to isomerisation, as $\mathbf{A}$ cannot evolve to any complex other than allyl-2. The higher stability of $\mathbf{B}$ could be related to the presence of agostic H-bonding $(1.97 \AA$ ) between Mo and one hydrogen atom of the terminal methyl group. In fact, the analogous compound lacking that $\mathrm{Mo} \cdots \mathrm{H}$ interaction was computationally found to be $5.0 \mathrm{kcal} / \mathrm{mol}$ higher in energy than B. Subsequent $\beta$-H elimination from either of the two diastereotopic hydrogen atoms of the silylmethylene group present in B results in two TSs of very different energy. The lowest of these two transition states, TS5, with an activation free energy of $10.7 \mathrm{kcal} / \mathrm{mol}\left(G_{\mathrm{TS} 5}-G_{\mathrm{B}}\right)$ gives complex trans-2, which affords, after coordination of one carbonyl ligand, the experimentally unique product of the allyl isomerisation, derivative trans-1. An alternative mechanism could be responsible for the transformation of cis-1 into trans-1. Indeed, both complexes are connected through a $\beta-\mathrm{H}$ insertion/elimination process, which involves metallacycle $\mathbf{C}$ as intermediate. This pathway represents an energetically less demanding process than the one occurring

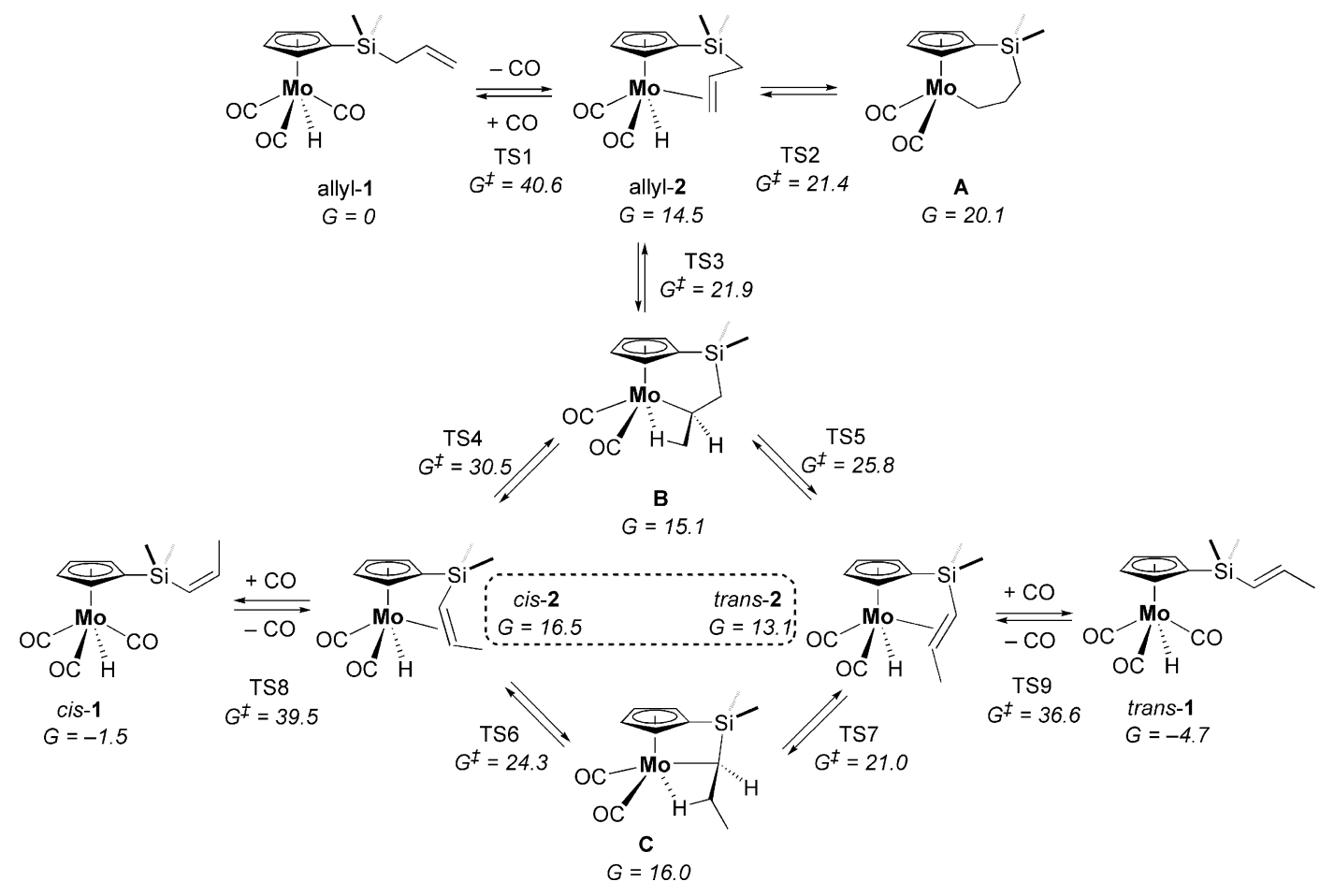

Figure 1. Reaction pathway for the intramolecular isomerisation of the pendant allyl unit present in molybdenum compound allyl-1. 


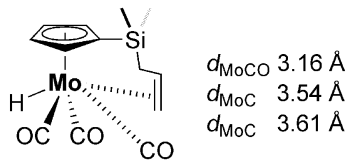

TS1

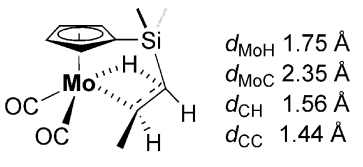

TS4

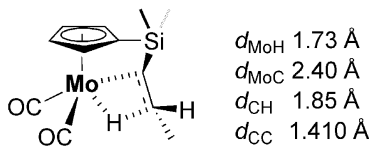

TS7

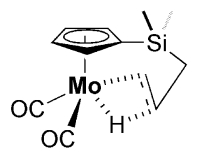

TS2

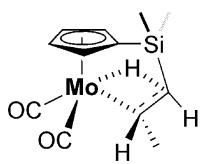

TS5

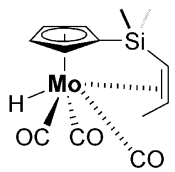

TS8
$d_{\mathrm{MoH}} 1.72 \AA$

$d_{\text {MoC }} 2.37 \AA$

$d_{\mathrm{CH}} 1.83 \AA$

$d_{\mathrm{CC}} 1.40 \AA$

$d_{\mathrm{MoH}} 1.75 \AA$

$d_{\mathrm{MoC}} 2.36 \AA$

$d_{\mathrm{CH}} 1.57 \AA$

$d_{\mathrm{CC}} 1.43 \AA$

$d_{\text {MoCO }} 3.35 \AA$

$d_{\mathrm{MoC}} 3.48 \AA$

$d_{\text {MoC }} 3.88 \AA$

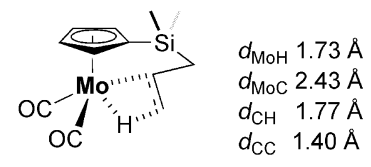

TS3

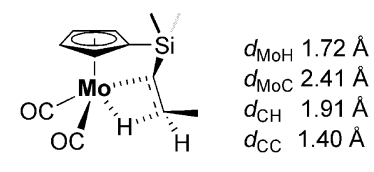

TS6

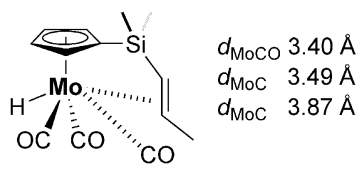

TS9

Figure 2. Transitions states TS1-TS9 and calculated relevant distances.

through intermediate $\mathbf{B}$, as transition states TS6 and TS7 (24.3 and $21.0 \mathrm{kcal} / \mathrm{mol}$, respectively) are ca. $11 \mathrm{kcal} / \mathrm{mol}$ lower in energy than corresponding TS4 and TS5. Noteworthy, an agostic Mo**H interaction (1.94 $\AA$ ) was found to be responsible for the stabilisation of $\mathbf{C}$ by ca. $4.1 \mathrm{kcal} /$ mol.

Moreover, metallacycles $\mathbf{B}$ and $\mathbf{C}$ might be competitive species in the equilibrium with the dicarbonyl olefin complexes trans- and cis-2. However, their tricarbonyl compound counterparts, B-2 and C-2, (Figure 3) are entropically disfavoured species, as they have fewer degrees of freedom than compounds trans- and cis-2. In these species, the coordination of $\mathrm{CO}$ provokes the entropically favoured decoordination of the olefin to afford trans- and cis-1, whereas a similar ligand coordination in $\mathbf{B}$ and $\mathbf{C}$ would split the agostic Mo-H interaction to afford B-2 and C-2, respectively.

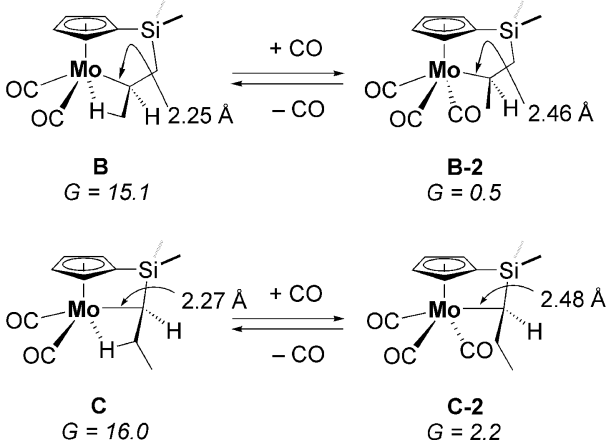

Figure 3. Free energies $(\mathrm{kcal} / \mathrm{mol})$ and some relevant bond lengths for compounds B, B-2, C and C-2.

Furthermore, the presence of three $\mathrm{CO}$ ligands weakens the Mo-C bond present in $\mathbf{B}$ and $\mathbf{C}$ up to $d_{\mathrm{Mo}-\mathrm{C}}>2.4 \AA$ (standard Mo-C bond is ca. $2.25 \AA$ ), further contributing to their instability. Comparison of the free energy values of B-2 $(0.5 \mathrm{kcal} / \mathrm{mol})$ and $\mathbf{C}-2(2.2 \mathrm{kcal} / \mathrm{mol})$ with those of cis$1(-1.5 \mathrm{kcal} / \mathrm{mol})$ and trans $-1(-4.7 \mathrm{kcal} / \mathrm{mol})$ also confirm the experimental results.

In summary, theoretical calculations for the intramolecular isomerisation reaction permit us to conclude that although six-membered zirconacycle derivative $\mathbf{2}$ is expected to be isolated, only the allyl or the methylvinyl cyclopentadienyl molybdenum compound can be synthesised, which agrees with the experimental observations. ${ }^{[7,8]}$

\section{Isomerisation of Alkenes}

In view of the results described above, we decided to test the cis/trans selectivity of similar group 4 and 6 cyclopentadienyl compounds lacking an alkene functionality in the cyclopentadienyl ring as catalysts of the well-known olefin isomerisation reaction. Thus, $\left[\mathrm{MH}\left(\eta^{5}-\mathrm{C}_{5} \mathrm{HMe}_{4}\right)(\mathrm{CO})_{3}\right][\mathrm{M}$ $=\mathrm{Mo}(3), \mathrm{W}$ (4)] and $\left[\mathrm{ZrH}\left(\eta^{5}-\mathrm{C}_{5} \mathrm{H}_{4} \mathrm{SiMe}_{2}-\eta^{1}-\mathrm{N} t \mathrm{Bu}\right)\left(\eta^{5}-\right.\right.$ $\left.\left.\mathrm{C}_{5} \mathrm{H}_{4} \mathrm{R}\right)\right]\left[\mathrm{R}=\mathrm{H}(\mathbf{5}), \mathrm{SiMe}_{3}(\mathbf{6})\right]$ were tested in the intermolecular isomerisation of terminal and internal alkenes. The results are summarised in Tables 1 and 2 .

We decided to use tetramethylcyclopentadienyl hydride species $\mathbf{3}$ and $\mathbf{4}$ as catalysts, rather than the corresponding nonsubstituted cyclopentadienyl hydride derivatives, which undergo dehydrogenation processes very easily to form the corresponding hexacarbonyl dimer compounds. However, for Mo the active species are not stable under these catalytic conditions and dehydrogenation of $\mathbf{3}$ towards the formation of the dinuclear complex $\left[\mathrm{Mo}\left(\eta^{5}-\mathrm{C}_{5} \mathrm{HMe}_{4}\right)(\mathrm{CO})_{3}\right]_{2}(7)$ was inferred from the ${ }^{1} \mathrm{H}$ NMR spectra of the $\left[\mathrm{D}_{6}\right]$ benzene reaction mixture. This thermal dehydrogenation of derivatives of the general formula $\left[\mathrm{MH}\left(\eta^{5}-\mathrm{C}_{5} \mathrm{R}_{5}\right)(\mathrm{CO})_{3}\right]$ is a wellknown and documented reaction, ${ }^{[10]}$ which is about two or 
Table 1. Isomerisation of olefins catalysed by Mo/W compounds 3 and 4.

\begin{tabular}{|c|c|c|c|c|c|c|}
\hline Entry & Substrate & Catalyst & $\begin{array}{c}{[\mathrm{Cat}] /[\mathrm{S}]} \\
{[\%]}\end{array}$ & Conditions $^{[\mathrm{a}]}$ & $\begin{array}{c}\text { Conversion }^{[\mathrm{b}]} \\
{[\%]}\end{array}$ & $\begin{array}{c}\text { Product distribution }^{[\mathrm{b}]} \\
{[\%]}\end{array}$ \\
\hline 1 & $\mathrm{SiMe}_{3} \mathrm{CH}_{2} \mathrm{CH}=\mathrm{CH}_{2}(\mathbf{A})$ & 3 & 1 & $100-140^{\circ} \mathrm{C}, 48 \mathrm{~h}$ & 0 & - \\
\hline 2 & & 3 & 10 & $48 \mathrm{~h}$ & 20 & $24: 76$ \\
\hline 3 & & 4 & 1.5 & $24 \mathrm{~h}$ & 20 & $24: 76$ \\
\hline 4 & & 4 & 1.5 & $48 \mathrm{~h}$ & 32 & $17: 83$ \\
\hline 5 & & 4 & 1.5 & $>72 \mathrm{~h}$ & 45 & $15: 85$ \\
\hline 6 & & 4 & 10 & $48 \mathrm{~h}$ & 69 & 9:91 \\
\hline 7 & $i \mathrm{PrCH}_{2} \mathrm{CH}=\mathrm{CH}_{2}(\mathbf{B})$ & 3 & 10 & $48 \mathrm{~h}$ & 15 & $42: 58$ \\
\hline 8 & & 4 & 10 & $48 \mathrm{~h}$ & 54 & $36: 64$ \\
\hline 9 & & 4 & 10 & $>72 \mathrm{~h}$ & 67 & $36: 64$ \\
\hline 10 & $\begin{array}{l}\text { cis }+ \text { trans }-\mathrm{SiMe}_{3} \mathrm{CH}=\mathrm{CHCH}_{3} \\
(\text { cis }+ \text { trans }-\mathrm{C})\end{array}$ & 3 & $1-20$ & $100-140^{\circ} \mathrm{C}, 48 \mathrm{~h}$ & 0 & - \\
\hline 11 & (cis/trans, 40:60) & 4 & 15 & $48 \mathrm{~h}$ & - & 9:76:15 \\
\hline 12 & cis- $t \mathrm{BuCH}=\mathrm{CHCH}_{3}$ (D) & 3 & $1-20$ & $100-140^{\circ} \mathrm{C}, 48 \mathrm{~h}$ & 0 & - \\
\hline 13 & & 4 & 15 & $48 \mathrm{~h}$ & 16 & $50: 50$ \\
\hline
\end{tabular}

[a] Reaction conditions: A Young-valved NMR tube was charged with a [ $\left.\mathrm{D}_{6}\right]$ benzene solution of the alkene and the catalyst, and the mixture was heated to $140{ }^{\circ} \mathrm{C}$. Entries 1,10 and 12 covered the indicated temperature and/or [Cat]/[S] ranges. [b] Conversions and product distributions were determined by ${ }^{1} \mathrm{H}$ and ${ }^{13} \mathrm{C}$ NMR spectroscopy. Product distributions for olefins $\mathbf{A}$ and $\mathbf{B}$ show the ratio of the cis/trans$\mathbf{C}$ and cis/trans-iPrCH$=\mathrm{CHCH}_{3}(\mathbf{E})$ isomer mixture, respectively. Total conversion cannot be calculated for olefin $\mathbf{C}$, as the substrate contained an initial 40:60 cis/trans isomer ratio, and thus only the final product distribution (cis-C/trans-C/A) is given. Product distribution for olefin $\mathbf{D}$ shows the ratio of trans-D and the terminal counterpart $t \mathrm{BuCH}_{2} \mathrm{CH}=\mathrm{CH}_{2}(\mathbf{F})$.

Table 2. Isomerisation of olefins catalysed by $\mathrm{Zr}$ compounds $\mathbf{5}$ and $\mathbf{6}$.

\begin{tabular}{|c|c|c|c|c|c|c|}
\hline Entry & Substrate & Catalyst & $\begin{array}{c}{[\mathrm{Cat}] /[\mathrm{S}]} \\
{[\%]}\end{array}$ & Conditions $^{[\mathrm{a}]}$ & $\begin{array}{c}\text { Conversion }^{[\mathrm{b}]} \\
{[\%]}\end{array}$ & $\begin{array}{c}\text { Product distribution }^{[\mathrm{b}]} \\
{[\%]}\end{array}$ \\
\hline 1 & $\mathrm{SiMe}_{3} \mathrm{CH}_{2} \mathrm{CH}=\mathrm{CH}_{2}(\mathbf{A})$ & 5 & 1 & $50{ }^{\circ} \mathrm{C}$ & 36 & $44: 56$ \\
\hline 2 & & 5 & 1 & $100^{\circ} \mathrm{C}$ & 59 & $30: 70$ \\
\hline 3 & & 5 & 1 & $120^{\circ} \mathrm{C}$ & 66 & $26: 74$ \\
\hline 4 & & 5 & 25 & r.t. & 36 & $48: 52$ \\
\hline 5 & & 5 & 25 & r.t., $>72 \mathrm{~h}$ & 58 & 25.75 \\
\hline 6 & & 6 & 1 & $50^{\circ} \mathrm{C}$ & 28 & $88: 12$ \\
\hline 7 & & 6 & 1 & $80^{\circ} \mathrm{C}$ & 41 & $54: 46$ \\
\hline 8 & & 6 & 1 & $100^{\circ} \mathrm{C}$ & 53 & $39: 61$ \\
\hline 9 & & 6 & 25 & $80^{\circ} \mathrm{C}$ & 51 & $14: 86$ \\
\hline 10 & $i \mathrm{PrCH}_{2} \mathrm{CH}=\mathrm{CH}_{2}(\mathbf{B})$ & 5 & 1 & $50{ }^{\circ} \mathrm{C}$ & 24 & $14: 86$ \\
\hline 11 & & 5 & 1 & $80^{\circ} \mathrm{C}$ & 41 & $9: 91$ \\
\hline 12 & & 5 & 1 & $80^{\circ} \mathrm{C},>72 \mathrm{~h}$ & 62 & $8: 92$ \\
\hline 13 & $\begin{array}{l}\text { cis }+ \text { trans }-\mathrm{SiMe}_{3} \mathrm{CH}=\mathrm{CHCH}_{3} \\
(\text { cis }+ \text { trans }-\mathrm{C})\end{array}$ & 5 & 6 & $50^{\circ} \mathrm{C}$ & - & $12: 88$ \\
\hline 14 & (cis/trans, 40:60) & 5 & 6 & $50^{\circ} \mathrm{C},>72 \mathrm{~h}$ & - & 0:100 \\
\hline 15 & $c i s-t \mathrm{BuCH}=\mathrm{CHCH}_{3}$ (D) & 5 & 6 & $80^{\circ} \mathrm{C}$ & 12 & $30: 70$ \\
\hline
\end{tabular}

[a] Reaction conditions: Young-valved NMR tube was charged with a $\left[\mathrm{D}_{6}\right]$ benzene solution of the alkene and the catalyst, and the mixture was heated at the temperature shown for $48 \mathrm{~h}$. [b] Conversions and product distributions were determined by ${ }^{1} \mathrm{H}$ and ${ }^{13} \mathrm{C}$ NMR spectroscopy. Product distributions for olefins $\mathbf{A}$ and $\mathbf{B}$ show the ratio of cis/trans- $\mathbf{C}$ and cis/trans-iPrCH$=\mathrm{CHCH}_{3}(\mathbf{E})$ isomer mixture, respectively. Total conversion cannot be calculated for olefin $\mathbf{C}$, as the substrate contained an initial 40:60 cis/trans isomer ratio, thus only the final product distribution (cis-C/trans-C) is given. Product distribution for olefin $\mathbf{D}$ shows the ratio of trans-D and the terminal counterpart $t \mathrm{BuCH}_{2} \mathrm{CH}=\mathrm{CH}_{2}(\mathbf{F})$.

three times faster for Mo than for W compounds and explains the differences in activities of each metal complex under the reaction conditions used in our experiments. In order to unambiguously confirm the formation of dinuclear compound 7 under these reaction conditions, we prepared this derivative by following a similar procedure as that used for the reported synthesis of $\left[\mathrm{Mo}\left(\eta^{5}-\mathrm{C}_{5} \mathrm{H}_{4} \mathrm{CH}_{2} \mathrm{CH}=\mathrm{CH}_{2}\right)\right.$ $\left.(\mathrm{CO})_{3}\right]_{2}{ }^{[7]}$ (Scheme 1). Thus, treatment at room temperature

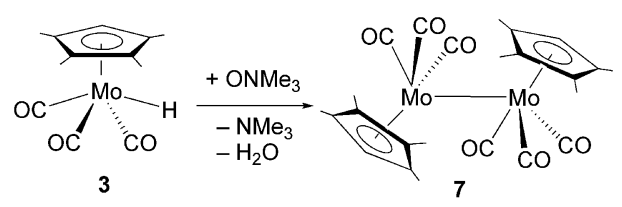

Scheme 1. 
of toluene solutions of $\mathbf{3}$ with trimethylamine oxide afforded a red solid that was characterised by ${ }^{1} \mathrm{H}$ and ${ }^{13} \mathrm{C}$ NMR and IR spectroscopy and elemental analysis as dinuclear compound 7. Although there are several examples of organometallic carbonyl clusters showing activity in alkene isomerisation reactions, ${ }^{[1,11]}$ the Mo dimer discussed showed no conversion of the olefins tested.

Group 6 metal compounds (Table 1) achieved isomerisation only at temperatures of ca. $140{ }^{\circ} \mathrm{C}$ and, in general, high catalyst concentrations increased conversions at this temperature. Both terminal alkenes allyltrimethylsilane (A) and 4-methyl-1-pentene (B) afforded their corresponding internal olefins trimethyl(1-propenyl) (C) and 4-methyl-2pentene, $i \mathrm{PrCH}=\mathrm{CHCH}_{3}(\mathbf{E})$, respectively, as a mixture of cis/trans isomers as shown in Table 1 (Entries 1-9). Congruent with the more thermodynamic stability of trans isomers, major production of trans- $\mathbf{C}$ and trans-E was favoured with long reaction times, reaching cis/trans product distributions up to 9:91 (Table 1, Entry 6) and 36:64 (Table 1, Entry 8), respectively, after $48 \mathrm{~h}$ at $140{ }^{\circ} \mathrm{C}$, and suggesting a cis-totrans isomerisation.

$\mathrm{Zr}$ catalysts $\mathbf{5}$ and $\mathbf{6}$, (Table 2) achieved isomerisation of terminal olefins $\mathbf{A}$ and $\mathbf{B}$ under milder conditions than those required for the Mo and W systems, even though higher temperatures and/or catalyst concentrations achieved better conversions. These reaction conditions also increased production of trans-C from olefin $\mathbf{A}$ (Table 2, Entries 1-9), whereas cis/trans-E distributions of ca. 10:90 were observed independent of the reaction temperature when $\mathbf{B}$ was the substrate (Table 2, Entries 10-12). Interestingly, there are differences between the cis/trans product distribution reached with unsubstituted cyclopentadienyl complex $\mathbf{5}$ and trimethylsilyl-substituted system $\mathbf{6}$, with cis-C productions of $44 \%$ (Table 2, Entry 1) and $88 \%$ (Table 2, Entry 6), respectively, under the same catalytic conditions. Accepting the traditional olefin insertion and $\beta-\mathrm{H}$ elimination mechanism for the isomerisation process catalysed by hydride metal compounds, catalyst $\mathbf{6}$ would give the most sterically hindered four-centred transient species for a trans-isomer formation, which would favour high cis-isomer production. An increase in the temperature and in the amount of catalyst had dramatic effects on the cis-isomer production of catalyst $\mathbf{6}$. Thus, the cis/trans- $\mathbf{C}$ isomer ratio changed from $88: 12$ at $50{ }^{\circ} \mathrm{C}$ up to $14: 86$ at $80{ }^{\circ} \mathrm{C}$ with $25 \%$ of catalyst loaded (Table 2, Entries 6-9) allowing the product distribution to be modulated by appropriate selection of the reaction conditions.

The presence in the substrate of a silyl substituent seems to have no important effect on the activities of any of the catalysts tested. Thus, catalysts $\mathbf{4 - 6}$ achieved only slightly higher conversions when A was used as substrate instead of B.

Internal alkenes $\mathbf{C}$ and 4,4-dimethyl-2-pentene (D) were tested in the isomerisation reaction in order to probe the cis to trans isomer transformation. Both $\mathbf{C}$ and $\mathbf{D}$ need higher concentrations of catalysts $\mathbf{4}$ and $\mathbf{5}$ than their terminal counterparts A or $\mathbf{B}$. As expected from their relative stabilities, internal olefins were converted, to some extent, into their terminal counterparts only at high temperatures (Table 1, Entries 11 and 13; Table 2, Entry 15). Rather, a cis-to-trans isomerisation was the favoured process at mild temperatures, which afforded, with catalyst $\mathbf{5}$ and olefin $\mathbf{C}$ (Table 2, Entries 14 and 15), a 0:100 cis/trans-C ratio. In the absence of catalyst, $\left[\mathrm{D}_{6}\right]$ benzene solutions of cis/trans-C and cis-D showed no modification of the isomer distribution after heating up to $150^{\circ} \mathrm{C}$ for 1 week.

The six-membered zirconacycle derivative $\left[\operatorname{Zr}\left(\eta^{5}-\right.\right.$ $\left.\left.\mathrm{C}_{5} \mathrm{H}_{4} \mathrm{SiMe}_{2}-\eta^{1}-\mathrm{N} t \mathrm{Bu}\right)\left(\eta^{5}-\mathrm{C}_{5} \mathrm{H}_{4} \mathrm{SiMe}_{2} \mathrm{CH}_{2} \mathrm{CH}_{2}-\eta^{1}-\mathrm{CH}_{2}\right)\right]$ (2) provides an example of a stable $\beta$-H containing $\mathrm{Zr}$-alkyl derivative $^{[6,8,12]}$ and has been proposed to model the transient $\mathrm{Zr}$-alkyl intermediates present in the isomerisation processes achieved by analogous cyclopentadienyl $\mathrm{Zr}$ hydride derivatives 5 or $6 .^{[8]}$ In order to explore the ability of 2 to give $\beta-\mathrm{H}$ elimination reactions, the zirconacycle compound was also tested in the isomerisation reaction of $\mathbf{A}$ in $\left[\mathrm{D}_{6}\right]$ benzene. Compound $\mathbf{2}$ afforded low conversions in the intermolecular allyltrimethylsilane isomerisation even at $140{ }^{\circ} \mathrm{C}$ with ca. $10 \%$ of catalyst loaded (Table 3 ). The most interesting feature is, however, that the ${ }^{1} \mathrm{H}$ NMR spectra of the reaction between $\mathbf{2}$ and allyltrimethylsilane always showed clean formation of $\mathbf{C}$ together with the set of signals due to zirconacycle derivative 2 .

Table 3. Allyltrimethylsilane isomerisation achieved by compound 2.

\begin{tabular}{lccc}
\hline Entry $^{[a]}$ & {$[2] /[\mathbf{A}]$} & $\begin{array}{c}\text { Conversion } \\
{[\%]}\end{array}$ & $\begin{array}{c}\text { Product distribu- } \\
\text { tion }^{[\mathrm{b}]} \\
{[\%]}\end{array}$ \\
\hline 1 & {$[\%]$} & {$[\%]$} & - \\
2 & 1 & 0 & $39: 61$ \\
3 & 10 & 15 & $0: 100$ \\
4 & 30 & 54 & $0: 100$
\end{tabular}

[a] Reaction conditions: Young-valved NMR tube was charged with a $\left[\mathrm{D}_{6}\right]$ benzene solution of $\mathbf{A}$ and $\mathbf{2}$, and the mixture was heated at $140{ }^{\circ} \mathrm{C}$ for $48 \mathrm{~h}$. [b] The isomerisation reaction afforded a mixture of cis/trans-C, conversions and \% cis/trans distribution were determined by ${ }^{1} \mathrm{H}$ NMR spectroscopy.

Recovery of unmodified compound $\mathbf{2}$ implies formation of zirconium hydride $\mathbf{1}$ as the active species of the isomerisation process (Scheme 2) and confirms the role of $\mathbf{2}$ as a model of transient $\mathrm{Zr}$-alkyl intermediates present in processes of this kind.

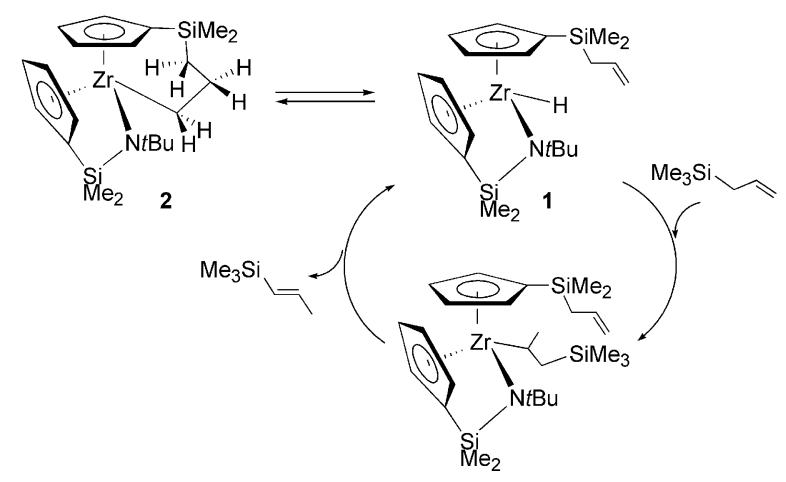

Scheme 2. 


\section{Conclusions}

A DFT computational study of the allyl isomerisation on the model compound $\left[\mathrm{MoH}\left(\eta^{5}-\mathrm{C}_{5} \mathrm{R}_{4} \mathrm{SiMe}_{2} \mathrm{CH}_{2} \mathrm{CH}=\mathrm{CH}_{2}\right)\right.$ $(\mathrm{CO})_{3}$ ] shows that trans-substituted complexes trans $\mathbf{- 1}$ and trans-2 are the most stable tri- and dicarbonyl species, respectively, which is consistent with the experimental results reported earlier. The results explain the reactivity differences between group $4^{[8]}$ and $6^{[7]}$ allyl cyclopentadienyl hydride compounds. An alternative isomerisation route was found computationally for the transformation of compound cis- to trans-2, showing a model example of the cis-to-trans isomer conversion.

Compounds $\left[\mathrm{WH}\left(\eta^{5}-\mathrm{C}_{5} \mathrm{HMe}_{4}\right)(\mathrm{CO})_{3}\right]$ (4) and $\left[\mathrm{ZrH}\left(\eta^{5}-\right.\right.$ $\left.\left.\mathrm{C}_{5} \mathrm{H}_{4} \mathrm{SiMe}_{2}-\eta^{1}-\mathrm{N} t \mathrm{Bu}\right)\left(\eta^{5}-\mathrm{C}_{5} \mathrm{H}_{4} \mathrm{R}\right)\right]\left[\mathrm{R}=\mathrm{H}(5), \mathrm{SiMe}_{3}(6)\right]$ can catalyse the isomerisation of 1-alkenes $\mathrm{Si}$ $\mathrm{Me}_{3} \mathrm{CH}_{2} \mathrm{CH}=\mathrm{CH}_{2}$ and $i \mathrm{PrCH}_{2} \mathrm{CH}=\mathrm{CH}_{2}$ to the corresponding internal olefins with, in general, high trans/cis isomer ratios. Reactions of catalysts $\mathbf{4}$ and $\mathbf{5}$ with the internal alkenes $\mathrm{SiMe}_{3} \mathrm{CH}=\mathrm{CHCH}_{3}$ and $t \mathrm{BuCH}=\mathrm{CHCH}_{3}$ strongly suggest that this trans selectivity in alkene production is due to a cis-to-trans isomerisation process analogous to that computationally found for intramolecular olefin isomerisation. In addition, conversion of $\mathrm{SiMe}_{3} \mathrm{CH}_{2} \mathrm{CH}=\mathrm{CH}_{2}$ to the corresponding olefin $\mathrm{SiMe}_{3} \mathrm{CH}=\mathrm{CHCH}_{3}$ with zirconacycle $\mathbf{2}$ demonstrates its role as a model for the transient $\mathrm{Zr}$-alkyl intermediates present in the isomerisation processes.

\section{Experimental Section}

Computational Methods: All reported structures were optimised at the DFT level by using the B3LYP ${ }^{[13]}$ hybrid functional as implemented in Gaussian 03. ${ }^{[14]}$ Optimisations were carried out by using the standard $6-31 \mathrm{G}^{*}$ basis set for $\mathrm{C}, \mathrm{H}, \mathrm{O}$ and $\mathrm{Si}$. The LANL2DZ basis set, which includes the relativistic effective core potential (ECP) of Hay and Wadt and employs a split-valence (double- $\zeta$ ) basis set, was used for Mo. ${ }^{[15]}$ All energy minima and transition structures were characterised by harmonic frequency analysis at the same level. The energies reported in this work include thermal and zero-point vibrational energy corrections (ZPVE) and are not scaled. The stationary points were characterised by frequency calculations in order to verify that they have the right number of negative eigenvalues. The intrinsic reaction coordinates (IRC) ${ }^{[16]}$ were followed to verify the energy profiles connecting each TS to the correct associated local minima. In the discussion and figures all energy values are relative to allyl-1, which was taken as $G=0$ energy.

General Information: All manipulations involving syntheses of metal complexes and catalysis were performed at an argon/vacuum manifold by using standard Schlenk-line techniques under an argon atmosphere or in a glove box MBraun MOD System. Solvents were dried by conventional procedures and freshly distilled prior to use. $\left[\mathrm{M}(\mathrm{NCMe})_{3}(\mathrm{CO})_{3}\right] \quad(\mathrm{M}=\mathrm{Mo}, \mathrm{W}),{ }^{[17]}\left[\mathrm{Zr}\left(\eta^{5}-\mathrm{C}_{5} \mathrm{H}_{4} \mathrm{SiMe}_{2}-\eta^{1}-\right.\right.$ $\left.\mathrm{N} t \mathrm{Bu})\left(\eta^{5}-\mathrm{C}_{5} \mathrm{H}_{4} \mathrm{SiMe}_{2} \mathrm{CH}_{2} \mathrm{CH}_{2}-\eta^{1}-\mathrm{CH}_{2}\right)\right] \quad(2),{ }^{[8]} \quad\left[\mathrm{MoH}\left(\eta^{5}-\right.\right.$ $\left.\left.\mathrm{C}_{5} \mathrm{HMe}_{4}\right)(\mathrm{CO})_{3}\right] \quad(3)^{[7]}$ and $\left[\mathrm{ZrH}\left(\eta^{5}-\mathrm{C}_{5} \mathrm{H}_{4} \mathrm{SiMe}_{2}-\eta^{1}-\mathrm{N} t \mathrm{Bu}\right)\left(\eta^{5}-\right.\right.$ $\left.\left.\mathrm{C}_{5} \mathrm{H}_{4} \mathrm{R}\right)\right]\left[\mathrm{R}=\mathrm{H}(\mathbf{5}), \mathrm{SiMe}_{3}(\mathbf{6})\right]^{[8]}$ were prepared according to previous reports. Commercially available reagents were used without further purification. NMR spectra were recorded with a Bruker 400 Ultrashield. ${ }^{1} \mathrm{H}$ and ${ }^{13} \mathrm{C}$ chemical shifts are reported relative to tetramethylsilane. Coupling constants $J$ are given in Hertz. IR spec- tra were measured with a Perkin-Elmer 883 IR spectrometer. Elemental analysis was performed in our laboratories (UAH) with a Perkin-Elmer 2400 CHNS/O Analyzer, Series II.

General Procedure for Isomerisation of Alkenes: The isomerisation reactions were carried out in a Young-valved NMR tube, which was charged with $\left[\mathrm{D}_{6}\right]$ benzene solutions of the corresponding catalyst and alkene. For catalysts 3 and 4, $1.66(1 \%)$ to $0.35(15 \%)$ $\mathrm{mmol}$ of the alkene was charged. For catalysts $\mathbf{5}$ and $\mathbf{6}, 2.8(1 \%)$ to $0.85(15 \%) \mathrm{mmol}$ of the alkene was loaded. In the experiments with compound 2, $5.8 \times 10^{-2}(10 \%), \quad 1.3 \times 10^{-2}(30 \%)$ and $8.9 \times 10^{-3}(50 \%) \mathrm{mmol}$ of allyltrimethylsilane were used. Exact $\%$ of [Cat $] /[\mathrm{S}]$ was inferred from the ${ }^{1} \mathrm{H}$ NMR spectrum of the mixture before heating. The reaction mixture was then warmed to the required temperature and the transformation monitored by ${ }^{1} \mathrm{H}$ NMR spectroscopy. Allyltrimethylsilane, 4-methyl-1-pentene, cis-4,4-dimethyl-2-pentene and cis+trans-trimethyl(1-propenyl)silane were used as received from Aldrich, without further purification. cisand trans-Trimethyl(1-propenyl)silane, allytrimethysilane and 4,4dimethyl-1-pentene were spectroscopically identified by comparison of ${ }^{1} \mathrm{H}$ and ${ }^{13} \mathrm{C}$ NMR spectra of commercially available samples. cis- and trans-4-Methyl-2-pentene ${ }^{[18]}$ and 4,4-dimethyl-1-pentene ${ }^{[19]}$ were spectroscopically characterised and identified by comparison of reported ${ }^{1} \mathrm{H}$ and ${ }^{13} \mathrm{C}$ NMR spectra of the olefins.

trans-4-Methyl-2-pentene (trans-E): ${ }^{1} \mathrm{H}$ NMR (plus HSQCGP, $\left.400 \mathrm{MHz}, \mathrm{C}_{6} \mathrm{D}_{6}\right): \delta=5.72\left(\mathrm{~m},{ }^{\text {trans }} J_{\mathrm{H}, \mathrm{H}}=12 \mathrm{~Hz},{ }^{4} J_{\mathrm{H}, \mathrm{H}}=1.2 \mathrm{~Hz}, 1\right.$ $\mathrm{H}$, $=\mathrm{CH}-\mathrm{Pr}), 5.34\left(\mathrm{dq},{ }^{\text {trans }} J_{\mathrm{H}, \mathrm{H}}=12 \mathrm{~Hz},{ }^{3} J_{\mathrm{H}, \mathrm{H}}=5.2 \mathrm{~Hz}, 1 \mathrm{H}\right.$, $=\mathrm{CH}-\mathrm{Me}), 2.18\left(\mathrm{~m},{ }^{3} J_{\mathrm{H}, \mathrm{H}}=6.8 \mathrm{~Hz}, 1 \mathrm{H},-\mathrm{CHMe}_{2}\right), 1.56\left(\mathrm{dd},{ }^{3} J_{\mathrm{H}, \mathrm{H}}\right.$ $\left.=5.2 \mathrm{~Hz},{ }^{4} J_{\mathrm{H}, \mathrm{H}}=1.2 \mathrm{~Hz}, 3 \mathrm{H}, \mathrm{CH}_{3}-\mathrm{CH}=\right), 0.93\left[\mathrm{~d},{ }^{3} J_{\mathrm{H}, \mathrm{H}}=6.8 \mathrm{~Hz}\right.$, $\left.6 \mathrm{H},-\mathrm{C}\left(\mathrm{CH}_{3}\right)_{2}\right] \mathrm{ppm} .{ }^{13} \mathrm{C} \mathrm{NMR}$ (plus APT, plus HSQCGP, $\left.100 \mathrm{MHz}, \mathrm{C}_{6} \mathrm{D}_{6}\right): \delta=139.7(+,=\mathrm{CH}-i \mathrm{Pr}), 122.5(+,=\mathrm{CH}-\mathrm{Me}), 32.2$ $\left(+,-\mathrm{CHMe}_{2}\right), 23.5\left[+, 3 \mathrm{H},\left(\mathrm{CH}_{3}\right)_{2}-\mathrm{CH}-\right], 18.7\left[+,-\mathrm{CH}\left(\mathrm{CH}_{3}\right)\right] \mathrm{ppm}$.

cis-4-Methyl-2-pentene (cis-E): ${ }^{1} \mathrm{H}$ NMR (plus HSQCGP, $\left.400 \mathrm{MHz}, \mathrm{C}_{6} \mathrm{D}_{6}\right): \delta=5.36-5.20(\mathrm{~m}, 2 \mathrm{H},=\mathrm{CHMe}+=\mathrm{CH}-i \mathrm{Pr})$, $2.55\left(\mathrm{~m},{ }^{3} J_{\mathrm{H}, \mathrm{H}}=6.4 \mathrm{~Hz}, 1 \mathrm{H},-\mathrm{CHMe}_{2}\right), 1.51\left(\mathrm{dd},{ }^{3} J_{\mathrm{H}, \mathrm{H}}=6.4 \mathrm{~Hz}\right.$, $\left.{ }^{4} J_{\mathrm{H}, \mathrm{H}}=1.6 \mathrm{~Hz}, 3 \mathrm{H}, \mathrm{CH} \mathrm{H}_{3} \mathrm{CH}=\right), 0.91\left[\mathrm{~d},{ }^{3} J_{\mathrm{H}, \mathrm{H}}=6.4 \mathrm{~Hz}, 6 \mathrm{H}\right.$, $\left.-\mathrm{C}\left(\mathrm{CH}_{3}\right)_{2}\right]$ ppm. ${ }^{13} \mathrm{C}$ NMR (plus APT, plus HSQCGP, $100 \mathrm{MHz}$, $\left.\mathrm{C}_{6} \mathrm{D}_{6}\right): \delta=139.2(+,=\mathrm{CH}-i \mathrm{Pr}), 122.2(+,=\mathrm{CH}-\mathrm{Me}), 27.1(+$, $\left.-\mathrm{CHMe}_{2}\right), 23.8\left[+, 3 \mathrm{H},\left(\mathrm{CH}_{3}\right)_{2}-\mathrm{CH}-\right], 13.4\left[+,-\mathrm{CH}\left(\mathrm{CH}_{3}\right)\right] \mathrm{ppm}$.

4,4-Dimethyl-1-pentene (F): ${ }^{1} \mathrm{H}$ NMR (plus HSQCGP, $400 \mathrm{MHz}$, $\left.\mathrm{C}_{6} \mathrm{D}_{6}\right): \delta=5.76(\mathrm{~m}, 1 \mathrm{H},=\mathrm{CH}-\mathrm{C}), 5.00\left(\mathrm{~m}, 2 \mathrm{H},=\mathrm{CH}_{2}\right), 1.86(\mathrm{~d}$, $\left.{ }^{3} J_{\mathrm{H}, \mathrm{H}}=8.0 \mathrm{~Hz}, 2 \mathrm{H},-\mathrm{CH}_{2}\right), 0.84\left[\mathrm{~s}, 9 \mathrm{H},-\mathrm{C}\left(\mathrm{CH}_{3}\right)_{3}\right] \mathrm{ppm} .{ }^{13} \mathrm{C} \mathrm{NMR}$ (plus APT, plus HSQCGP, $\left.100 \mathrm{MHz}, \mathrm{C}_{6} \mathrm{D}_{6}\right): \delta=136.9(+,=\mathrm{CH})$, $117.4 \quad\left(-,=\mathrm{CH}_{2}\right), 49.3 \quad\left(-,-\mathrm{CH}_{2}\right), 30.0 \quad\left(-, \mathrm{Me}_{3} \mathrm{C}-\right), 12.8 \quad[+$, $\left.-\mathrm{C}\left(\mathrm{CH}_{3}\right)_{3}\right] \mathrm{ppm}$.

[WH $\left.\left(\boldsymbol{\eta}^{\mathbf{5}}-\mathbf{C}_{5} \mathbf{H M e}_{4}\right)(\mathbf{C O})_{3}\right]$ (4): An analogous procedure to that used to synthesise the reported $\left[\mathrm{MoH}\left(\eta^{5}-\mathrm{C}_{5} \mathrm{HMe}_{4}\right)(\mathrm{CO})_{3}\right](3)^{[7]}$ was followed. A THF solution of commercially available tetramethylcyclopentadiene $\left(\mathrm{C}_{5} \mathrm{H}_{2} \mathrm{Me}_{4} ; 0.18 \mathrm{~g}, 1.40 \mathrm{mmol}\right)$ was added to dry $\left[\mathrm{W}(\mathrm{CO})_{3}(\mathrm{NCMe})_{3}\right](0.5 \mathrm{~g}, 1.20 \mathrm{mmol})$, and the mixture was stirred at room temperature for $8 \mathrm{~h}$. After solvent evaporation and extraction of the orange solid residue into hexane, an orange solution was obtained, which afforded, after solvent removal, derivative 4 as an orange oil. Yield: $0.25 \mathrm{~g}(53 \%) . \mathrm{C}_{12} \mathrm{O}_{3} \mathrm{H}_{14} \mathrm{~W}$ (390.08): calcd. C 36.95, H 3.59; found C 37.10, H 3.77. IR (THF): $\tilde{v}=(C O) 2007$, $1909 \mathrm{~cm}^{-1} .{ }^{1} \mathrm{H}$ NMR $\left(400 \mathrm{MHz}, \mathrm{C}_{6} \mathrm{D}_{6}\right): \delta=4.57$ (s, $\left.1 \mathrm{H}, \mathrm{Cp}: \mathrm{CH}\right)$, 1.67, 1.68 (both s, each $6 \mathrm{H}, \mathrm{Cp}$ : $-\mathrm{CH}_{3}$ ), -6.58 (s, $\left.1 \mathrm{H}, \mathrm{W}-\mathrm{H}\right) \mathrm{ppm}$. ${ }^{13} \mathrm{C}$ NMR (plus APT, $\left.100 \mathrm{MHz}, \mathrm{C}_{6} \mathrm{D}_{6}\right): \delta=221.5(-, \mathrm{CO}), 103.6$, 106.8 (both -, Cp ${ }^{\text {ipso }}$ : C-Me), 87.9 (+, Cp: C-H), 11.6, 13.4 (both ,$\left.+-\mathrm{CH}_{3}\right) \mathrm{ppm}$.

$\left[\mathbf{M o}\left(\boldsymbol{\eta}^{5}-\mathbf{C}_{5} \mathbf{H M e}_{4}\right)(\mathbf{C O})_{3}\right]_{2}(\mathbf{7}):$ Toluene $(5 \mathrm{~mL})$ was added to a dry mixture of $3(0.5 \mathrm{~g}, 1.65 \mathrm{mmol})$ and trimethylamine oxide $(0.10 \mathrm{~g}$, 
$1.65 \mathrm{mmol})$. Stirring the reaction mixture for $12 \mathrm{~h}$ at room temperature gave a red solution. The solvent was removed under vacuum, and the solid residue was washed with hexane $(2 \times 3 \mathrm{~mL})$ and dried under vacuum to give a red solid. Yield: $0.90 \mathrm{~g}(89 \%)$. $\mathrm{C}_{24} \mathrm{H}_{26} \mathrm{Mo}_{2} \mathrm{O}_{6}$ (602.34): calcd. C 47.86, $\mathrm{H} 4.35$; found $\mathrm{C} 48.10, \mathrm{H}$ 4.26. IR (THF): $\tilde{v}=(\mathrm{CO}) 2008,1900 \mathrm{~cm}^{-1} .{ }^{1} \mathrm{H}$ NMR $(400 \mathrm{MHz}$, $\mathrm{C}_{6} \mathrm{D}_{6}$ ): $\delta=4.5$ (s, $1 \mathrm{H}, \mathrm{Cp}:-\mathrm{CH}$ ), 1.72, 1.77 (both s, each $6 \mathrm{H}, \mathrm{Cp}$ : $-\mathrm{CH}_{3}$ ) ppm. ${ }^{13} \mathrm{C}$ NMR (plus APT, $\left.100 \mathrm{MHz}, \mathrm{C}_{6} \mathrm{D}_{6}\right): \delta=234.9(-$, CO), 107.3, 105.5 (both -, Cp ${ }^{\text {ipso }}$ : C-Me), 92.4 (+, Cp: CH), 10.4, 12.6 (both,$+ \mathrm{Cp}$ : $-\mathrm{CH}_{3}$ ) ppm.

Supporting Information (see also the footnote on the first page of this article): Cartesian coordinates of the DFT optimised compounds.

\section{Acknowledgments}

Financial support from the Dirección General de Investigación Científica y Técnica of Spain (Project MAT2007-60997), Comunidad Autónoma de Madrid (Project S-0505/PPQ/0328), Universidad de Alcalá, UAH (Project CCG08-UAH/PPQ-4026) and Agencia Internacional Española de Cooperación Internacional, AECI, (Project A/011454/07) is acknowledged. E.R. thanks the Ministerio de Educación y Ciencia of Spain for funding through the RYC Program. C.E.P. and G.C. acknowledge UAH and AECI, respectively, for fellowships.

[1] A. Sivaramakrishna, P. Mushonga, I. L. Rogers, F. Zheng, R. J. Haines, E. Nordlander, J. R. Moss, Polyhedron 2008, 27, 19111916 and references cited therein.

[2] W. A. Herrmann, M. Prinz, Applied Homogeneous Catalysis with Organometallic Compounds, 2nd ed., Wiley-VCH, Weinheim, 2002, vol. 3; R. A. v. Santen, P. W. N. M. v. Leeuwen, J. A. Moulijn, B. A. Averill, Catalysis: An integrated approach, 2nd ed., Elsevier, Amsterdam, 1999.

[3] R. J. Keaton, L. R. Sita, J. Am. Chem. Soc. 2002, 124, 90709071; J. R. Krumper, M. Gerisch, J. M. Suh, R. G. Bergman, T. D. Tilley, J. Org. Chem. 2003, 68, 9705-9710; E. Shaviv, M. Botoshansky, M.S. Eisen, J. Organomet. Chem. 2003, 683, 165-180; S. Tobisch, Chem. Eur. J. 2003, 9, 1217-1232; S. Tobisch, R. Taube, J. Organomet. Chem. 2003, 683, 181-190; I. Lee, F. Zaera, J. Am. Chem. Soc. 2005, 127, 12174-12175.

[4] C. A. Tolman, J. Am. Chem. Soc. 94 1972, 2994-2999; C. P. Casey, C. R. Cyr, J. Am. Chem. Soc. 1973, 95, 2248-2253; K. Tanaka in Comprehensive Organometallic Chemistry III (Eds.: R. H. Crabtree, D. M. Mingos), Elsevier, Oxford, UK, 2007, vol. 10, pp. 71-99; G. W. Parshall, S. D. Ittel, Homogeneous Catalysis, 2nd ed., John Wiley and Sons, New York, 1992; J. F. Harrod, A. J. Chalk, J. Am. Chem. Soc. 1966, 88, 3491-3497.

[5] M. H. Prosenc, H. H. Brintzinger, Organometallics 1997, 16, 3889-3894; C. Averbuj, M. S. Eisen, J. Am. Chem. Soc. 1999, 121, 8755-8759; T. C. Morrill, C. A. D'Souza, Organometallics 2003, 22, 1626-1629; P. J. Chirik, N. F. Dalleska, L. M. Henling, J. E. Bercaw, Organometallics 2005, 24, 2789-2794; C. Masters, Homogeneous Transition-Metal Catalysis, Chapman and Hall, New York, 1981; S. Otsuka, K. Tani, Transition Metals for Organic Synthesis, Wiley-VCH, Weinheim, 1998, vol. 1; J. P. Collman, L. S. Hegedus, J. R. Norton, R. G. Fink, Principles and Applications of Organotransition Metal Chemistry, University Science, Mill Valley, CA, 1987.
[6] R. J. Keaton, L. R. Sita, Organometallics 2002, 21, 4315-4317; M. B. Harney, R. J. Keaton, L. R. Sita, J. Am. Chem. Soc. 2004, 126, 4536-4537.

[7] E. Royo, S. Acebrón, M. E. G. Mosquera, P. Royo, Organometallics 2007, 26, 3831-3839 and references cited therein.

[8] C. E. Petrisor, L. M. Frutos, O. Castaño, M. E. G. Mosquera, E. Royo, T. Cuenca, Dalton Trans. 2008, 2670-2673 and ref therein.

[9] E. Otten, A. Meetsma, B. Hessen, J. Am. Chem. Soc. 2007, 129, 10100-10101 and references cited therein; T. Z. Wu, Y. L. Qian, J. L. Huang, J. Mol. Catal. A 2004, 214, 227-229 and references cited therein; L. Lukesova, M. Horacek, P. Stepnicka, R. Gyepes, I. Cisarova, J. Kubista, K. Mach, J. Organomet. Chem. 2004, 689, 1919-1929 and references cited therein; P. Nicolás, P. Royo, M. V. Galakhov, O. Blacque, H. Jacobsen, H. Berke, Dalton Trans. 2004, 2943-2951; S. Tobisch, T. Ziegler, Organometallics 2003, 22, 5392-5405; C. G. Brandow, A. Mendiratta, J. E. Bercaw, Organometallics 2001, 20, 4253-4261; M. V. Galakhov, G. Heinz, P. Royo, Chem. Commun. 1998, 17-18.

[10] G. J. Kubas, H. J. Wasserman, R. R. Ryan, Organometallics 1985, 4, 2012-2021; K. A. Mahmoud, A. J. Rest, H. G. Alt, J. Chem. Soc., Dalton Trans. 1984, 187-197; H. G. J. Alt, K. A. Mahmoud, A. J. Rest, Angew. Chem. Int. Ed. Engl. 1983, 22, 544-545; R. L. Sweany, J. Am. Chem. Soc. 1986, 108, 69866991.

[11] A. Salvini, P. Frediani, F. Piacenti, J. Mol. Catal. A 2000, 159, 185-195.

[12] R. J. Keaton, L. A. Koterwas, J. C. Fettinger, L. R. Sita, J. Am. Chem. Soc. 2002, 124, 5932-5933.

[13] W. Kohn, A. D. Becke, R. G. Parr, J. Phys. Chem. 1996, 100, 12974-12980; A. D. Becke, J. Chem. Phys. 1993, 98, 5648-5652; C. T. Lee, W. T. Yang, R. G. Parr, Phys. Rev. B 1988, 37, 785789

[14] M. J. Frisch, G. W. Trucks, H. B. Schlegel, G. E. Scuseria, M. A. Robb, J. R. Cheeseman, J. A. Montgomery Jr, T. Vreven, K. N. Kudin, J. C. Burant, J. M. Millam, S. S. Iyengar, J. Tomasi, V. Barone, B. Mennucci, M. Cossi, G. Scalmani, N. Rega, G. A. Petersson, H. Nakatsuji, M. Hada, M. Ehara, K. Toyota, R. Fukuda, J. Hasegawa, M. Ishida, T. Nakajima, Y. Honda, O. Kitao, H. Nakai, M. Klene, X. Li, J. E. Knox, H. P. Hratchian, J. B. Cross, V. Bakken, C. Adamo, J. Jaramillo, R. Gomperts, R. E. Stratmann, O. Yazyev, A. J. Austin, R. Cammi, C. Pomelli, J. W. Ochterski, P. Y. Ayala, K. Morokuma, G. A. Voth, P. Salvador, J. J. Dannenberg, V. G. Zakrzewski, S. Dapprich, A. D. Daniels, M. C. Strain, O. Farkas, D. K. Malick, A. D. Rabuck, K. Raghavachari, J. B. Foresman, J. V. Ortiz, Q. Cui, A. G. Baboul, S. Clifford, J. Cioslowski, B. B. Stefanov, G. Liu, A. Liashenko, P. Piskorz, I. Komaromi, R. L. Martin, D. J. Fox, T. Keith, M. A. Al-Laham, C. Y. Peng, A. Nanayakkara, M. Challacombe, P. M. W. Gill, B. Johnson, W. Chen, M. W. Wong, C. Gonzalez, J. A. Pople, Gaussian 03, Revision E.01, Gaussian, Inc., Wallingford, CT 2004.

[15] P. J. Hay, W. R. Wadt, J. Chem. Phys. 1985, 82, 270-283; P. J. Hay, W. R. Wadt, J. Chem. Phys. 1985, 82, 284-298; P. J. Hay, W. R. Wadt, J. Chem. Phys. 1985, 82, 299-310.

[16] C. González, J. J. W. McDouall, H. B. Schlegel, J. Phys. Chem. 1990, 94, 7467-7471.

[17] F. Edelmann, P. Behrens, S. Behrens, U. Behrens, J. Organomet. Chem. 1986, 310, 333-355.

[18] D. Barillier, M. P. Strobel, L. Morin, D. Paquer, Tetrahedron 1983, 39, 767-775; D. E. Dorman, M. Jautelat, J. D. Roberts, J. Org. Chem. 1971, 36, 2757-2766.

[19] E. A. Hill, D. C. Link, P. Donndelinger, J. Org. Chem. 1981, 46, 1177-1182; R. A. Friedel, H. L. Retcofsky, J. Am. Chem. Soc. 1963, 85, 1300-1306.

Received: January 19, 2009 Published Online: March 12, 2009 